\title{
PENGARUH MODEL PEMBELAJARAN DISCOVERY LEARNING DENGAN MENGGUNAKAN MEDIAVIDEO TERHADAP HASIL BELAJAR SISWA
}

\author{
Aprilia Rahmayani \\ Universitas PGRI Semarang \\ Email : apriliarahmayani61@gmail.com
}

\begin{abstract}
Abstrak
Tujuan dari penelitian ini adalah untuk mengetahui pengaruh model pembelajaran Discovery Learning dengan menggunakan media video tehadap hasil belajar siswa kelas IV SD. Jenis penelitian ini adalah penelitian kuantitatif dalam bentuk Pre-Experimental Design dengan jenis One Group Pretest-Posttest. Populasi penelitian ini adalah siswa kelas IV SD N Gemah. Sampel yang digunakan pada penelitian ini adalah siswa kelas IV SD N Gemah yang terdiri dari 40 siswa dengan menggunakan teknik sampling yang terkumpul kemudian dianalisis menggunakan uji-t. Dalam pengumpulan data menggunakan teknik observasi,dan wawancara.
\end{abstract}

Kata Kunci : Discovery Learning, Video, Hasil Belajar

\begin{abstract}
The purpose of this study was to determine the effect of the Discovery Learning learning model using video media on the learning outcomes of fourth grade elementary school students. This type of research is quantitative research in the form of Pre-Experimental Design with the type of Pretest-Posttest One Group. The population of this study was grade IV SD N Gemah students. The sample used in this study is the fourth grade students of SD N Gemah consisting of 40 students using the collected sampling technique and then analyzed using the t-test. In collecting data using observation techniques, and interviews.
\end{abstract}

Keywords : Discovery Learning, Video, Learning Outcomes.

\section{PENDAHULUAN}

Dalam merancang pembelajaran yang efektif dan bermakna dalam pemilihan model pembelajaran yang tepat, maka dibutuhkan kemampuan guru dalam menguasai suatu model pembelajaran yang akan diterapkan, karena akan membantu proses pembelajaran yang efektif dan bermakna. Keberhasilan suatu proses kegiatan pembelajaran dapat dilihat dari hasil belajar dari peserta didik. Nilai sebagai hasil belajar sebagai tolak ukur kinerja gurudalam proses pembelajaran, serta nilai sebagai hasil belajar bagi siswa dalam keberhasilan proses kegiatan pembelajaran. Dalam memilih model pembelajaran, guru harus memilih model pembelajaran yang kreatif dan inovatif. Model pembelajaran yang menyenangkan serta menarik perhatian siswa, sesuai dengan materi yang akan disampaikan, sesuai dengan tujuan pembelajaran yang akan dicapai. Model pembelajaran adalah kerangka konseptual yang melukiskan prosedur yang sistematis dalam mengorganisasikan pengalaman belajar untuk mencapai tujuan belajar tertentu, dan berfungsi sebagai pedoman bagi para perancang pembelajaran dan pengajar dalam merencanakan aktivitas belajar mengajar, Soekamto (dalam (Shoimin 68AD)).

Hasil observasi di SD Negeri Gemah Semarang. Data menunjukkan bahwa hasil belajar siswa kelas IV yang masih rendah, karena siswa sering kali merasa kesulitan dalam menerima materi pelajaran yang akan mereka pelajari. Berdasarkan analisis hasil belajar yang dicapai peserta didik bisa dipengaruhi dua faktor yaitu faktor internal dan eksternal (Slameto, 2003: 54) Penyebab utama kesulitan belajar (learning disabillites) adalah faktor intermal diantaranya yaitu minat, motivasi, tingkat intellegensi, sedangkan penyebab utama problema belajar (learning problems) adalaha faktor eksternal diantaranya berupa strategi pembelajaran, pengelolaan kegiatan pembelajaran, serta faktor lingkungan yang mempengaruhi prestasi belajar yang dicapai oleh siswa .

Berdasarkan permasalahan tersebut dalam pelaksanaan kegiatan pembelajaran yang berperan penting ialah guru. Guru harus menyiapkan strategi pembelajaran agar proses pembelajaran tidak bersifat konvensional. Pembelajaran yang cenderung bersifat teacher-centered, sehingga siswa kurang aktif terhadap proses pembelajaran. Kurangnya inovasi pada model pembelajaran menjadikan peserta didik merasa bosan.

Untuk itu diperlukan, upaya pencapaian kondisi dengan penggunaan model pembelajaran yang dapat membuat siswa dapat aktif mengeluarkan pendapatnya dan menemukan konsepnya sendiri yaitu dengan menggunakan model pembelajaran Discovery Learning. Menurut Sardiman (2012: 145)“ Dalam mengaplikasikan model pembelajaran Discovery Learning guru berperan sebagai pembimbing dengan memberikan kesempatan kepada siswa untuk belajar aktif'. Model pembelajaran Discovery Learning merupakan salah satu model pembelajaran dimana guru tidak langsung memberikan hasil akhir atau kesimpulan dari materi yang disampaikannya.Melainkan siswa diberikan kesempatan 
utnuk mencari dan menemukan hasil data tersebut. Sehingga proses pembelajaran ini yang akan diingat oleh siswa sepanjang masa, sehingga hasil yang ia dapat tidak mudah dilupakan.

Penggunaan model discovery learning akan mengubah suatu proses pembelajaran yang bersifat fokus ke guru beralih ke situasi pembelajaran yang berpusat pada siswa. Model discovery learning merupakan suatu model pembelajaran yang menjadikan siswa aktif dalam menemukan, memecahkan suatu permasalahan melalui bimbingan dari guru siswa akan di arahkan mencari suatu informasi, mengolah, dan membahasnya kedalam kelompok masing-masing. Hal tersebut diperkuat dengan penelitian sebelumnya yang menggunakan model discovery learning yang dilakukan oleh Era Yanti bersama Erlinawati dari Zulkifli dengan penelitian yang berjudul "Penerapan Model Pembelajaran Discovery Learning Dapat Meningkatkan Hasil Belajar IPA Siswa Kelas II SD N 169 Pekanbaru" tahun 2015. Menunjukkan bahwa adanya hasil belajar pada siswa yang belum mencapai KKM disebabkan adanya cara belajar yang belum bisa membangkitkan hasil belajar siswa, cara dan teknik dalam pembelajaran menggunakan model ceramah. Sehingga pembelajaran tersebut menjadi monoton, serta kurang menjadikan siswa menjadi pasif dan kurang aktif dalam pembelajaran.Masalah yang di alami peneliti tersebut sama dengan permasalahan yang akan diteliti oleh peneliti di SD Negeri Gemah Semarang. Proses pembelajaran masih bersifat teacher-centered atau pembelajaran yang masih berfokus pada guru, sehingga menjadikan pembelajaran bersifat monoton dan siswa menjadi malas dalam mengikuti proses pembelajaran dan menjadikan rendahnya hasil belajar siswa pada kelas II serta banyaknya siswa yang belum mencapai KKM (Kriteria ketuntasan minimal yang ditetapkan oleh sekolah yaitu 75 .

Dalam upaya meningkatkan hasil belajar siswa, seorang guru harus menggunakan suatu model pembelajaran yang kreatif serta inovatif yang dapat meningkatkan aktivitas dalam pembelajaran sehingga pembelajaran dapat berjalan dengan aktif, dan penggunaan model atau media pembelajaran yang sesuai dengan materi yang akan di sampaikan serta dapat menarik perhatian siswa. Penggunaan model discovery learning akan mengubah suatu proses pembelajaran yang bersifat fokus ke guru beralih ke situasi pembelajaran yang berpusat pada siswa. Model discovery learning merupakan suatu model pembelajaran yang menjadikan siswa aktif dalam menemukan, memecahkan suatu permasalahan melalui bimbingan dari guru siswa akan di arahkan mencari suatu informasi, mengolah, dan membahasnya kedalam kelompok masing-masing. Hal tersebut diperkuat dengan penelitian sebelumnya yang menggunakan model discovery learning yang dilakukan oleh Era Yanti bersama Erlinawati dari Zulkifli dengan penelitian yang berjudul "Penerapan Model Pembelajaran Discovery Learning Dapat Meningkatkan Hasil Belajar IPA Siswa Kelas II SD N 169 Pekanbaru” Tahun 2015. Menunjukkan bahwa adanya hasil belajar pada siswa yang belum mencapai KKM disebabkan adanya cara belajar yang belum bisa membangkitkan hasil belajar siswa, cara dan teknik dalam pembelajaran menggunakan model ceramah. Sehingga pembelajaran tersebut menjadi monoton, serta kurang menjadikan siswa menjadi pasif dan kurang aktif dalam pembelajaran. Masalah yang di alami peneliti tersebut sama dengan permasalahan yang akan diteliti oleh peneliti di SD Negeri Gemah Semarang. Proses pembelajaran masih bersifat teacher-centered atau pembelajaran yang masih berfokus pada guru, sehingga menjadikan pembelajaran bersifat monoton dan siswa menjadi malas dalam mengikuti proses pembelajaran dan menjadikan rendahnya hasil belajar siswa pada kelas II serta banyaknya siswa yang belum mencapai KKM (Kriteria ketuntasan minimal yang ditetapkan oleh sekolah yaitu 75. Dalam upaya meningkatkan hasil belajar siswa, seorang guru harus menggunakan suatu model pembelajaran yang kreatif serta inovatif yang dapat meningkatkan aktivitas dalam pembelajaran sehingga pembelajaran dapat berjalan dengan aktif, dan penggunaan model atau media pembelajaran yang sesuai dengan materi yang akan di sampaikan serta dapat menarik perhatian siswa. Salah satu media pembelajaran yang dapat di gunakan yaitu media pembelajaran berbasis teknologi berupa video pembelajaran.

Dari ulasan tersebut, permasalahan yang akan diteliti adalah: Pengaruh Model Pembelajaran Discovery Learning Dengan Menggunakan Media Video Terhadap Hasil Belajar Siswa Kelas IV SD Negeri Gemah Semarang.

\section{METODE}

Lokasi penelitian ini akan dilaksanakan di Sekolah Dasar Negeri Gemah Semarang. Dalam penelitian ini menggunakan metode penelitian kuantitatif. Alasan menggunakan metode kuantitatif karena penelitian kuantitatif menggunakan data statistik yang berupa angka sebagai alat untuk menentukan jawaban terhadap persoalan, sehingga hasil penelitian tersusun secara sistematis dan pasti. Penelitian ini bertujuan untuk mengetahui pengaruh model pembelajaran Discovery Learning dengan menggunakan media video terhadap hasil belajar siswa kelas IV SD. Metode yang nantinya akan digunakan dalam penelitian ini adalah eksperimen yang termasuk dalam metode kuantitatif. Penelitian ini nantinya akan menggunakan Pre-Experimental Design dengan bentuk One-Grup Pretest-Posttest Design.

Populasi adalah wilayah generalisasi yang terdiri atas: obyek/subyek yang mempunyai kualitas dan karakteristik tertentu yang ditetapkan oleh peneliti untuk dipelajari dan kemudian ditarik suatu kesimpulannya. (Sugiyono 2013: 117), Jadi populasi dalam penelitian ini nantinya adalah seluruh siswa kelas IV SD Negeri Gemah Semarang. Teknik sampling yang akan digunakan yaitu teknik sampling Nonprobality sampling dengan sampling jenuh. Teknik pengumpulan data yang nantinya akan digunakan dalam penilitian ini yaitu observasi, tes wawancara, dan dokumentasi. Untuk tingkat analisis data terdiri dari analisis data awal menggunakan uji normalitas, untuk analisis data akhir terdiri dari uji normalitas akhir, uji homogenitas, uji t-test. 


\section{HASIL DAN PEMBAHASAN}

Berhasil atau tidaknya kurikulum 2013 dalam menghasilkan insan yang produktif, kreatif, dan inovatif melalui penguatan sikap, keterampilan, dan pengetahuan yang terintegrasi. Untuk mewujudkan hal tersebut, implementasi kurikulum, guru dituntut untuk secara professional merancang pembelajaran efektif dan bermakna, mengorganisasikan suatu pembelajaran, memilih serta menentukan model pembelajaran yang tepat, melaksanakan pembelajaran sesuai dengan kompetensi dan karakter, serta menetapkan kriteria keberhasilan yang harus dicapai. Dalam mewujudkan hal tersebut, salah satu faktor diantaranya adalah guru dalam merancang pembelajaran, karena secara langsung guru dapat mempengaruhi, meningkatkan kercerdasan dan keterampilan siswa. Untuk merancang pembelajaran yang efektif dan bermakna diharapkan guru harus menguasai prinsip-prinsip pembelajaran, pemilihan dan penggunaan model pembelajaran yang tepat dan sesuai dengan tujuan yang telah ditetapkan.

Untuk solusi dalam permasalahan tersebut maka dilakukan tindakan khususnya dalam strategi pembelajaran yaitu dengan menggunakan suatu model pembelajaran dan media pembelajaran yang inovatif dan menarik perhatian siswa yang nantinya akan memberikan dampak yang positif terhadap pemahaman dan hasil belajar siswa. Model pembelajaran yang dapat digunakan yaitu model pembelajaran Discovery Learning dengan tujuan untuk meningkatkan hasil belajar siswa. Melalui model Discovery Learning menjadikan siswa lebih aktif, berfikir kritis, serta dapat menumbuhkan kemampuan siswa dalam memecahlan suatu permasalahan. Model pembelajaran berbasis penemuan atau Discovery Learning, menurut (Cahyo 2013) merupakan suatu model pembelajaran yang mengatur pembelajaran sedemikian rupa hingga anak memperoleh pengetahuan yang sebelumnya belum diketahuinya tidak melalui pemberitahuan, namun ditemukan sendiri.

Berdasarkan landasan teori yang telah diuraikan maka dapat dirumuskan hipotesis sebagai berikut:

Ho $=$ Model pembelajaran Discovery Learning dengan menggunakan media video tidak berpengaruh terhadap hasil belajar siswa kelas IV SD Negeri Gemah.

$\mathrm{Ha}=$ Model pembelajaran Discovery Learning dengan menggunakan media video berpengaruh terhadap hasil belajar siswa kelas IV SD Negeri Gemah.

\section{PENUTUP}

\section{Simpulan}

Berdasarkan pembahasan diatas maka dapat disimpulkan bahwa model pembelajaran Discovery Learning merupakan model pembelajaran yang mengembangkan cara belajar aktif dan kreatif, dalam mengamati, menemukan, serta memcahkn masalah sendiri. Sehingga hasil yang didapat memberikan pengalaman langsung kepada siswa dan tidak mudah dilupakan siswa. Pembelajaran menggunakan model
Discovery Learning dapat meningkatkan aktivitas siswa dalam pembelajaran, membuat siswa bersemangat dalam belajar, dan meningkatkan hasil belajar siswa (Wahyudi, 2015).

\section{Saran}

Guru dapat memanfaatkan model pembelajaran yang kreatif untuk mendukung proes pembelajaran.

\section{DAFTAR PUSTAKA}

A.M. Sardiman. 2012. Interaksi dan Motivasi Belajar Mengajar. Jakarta: Rajawali Press.

Arikunto, Suharsimi. 2010. Prosedur Penelitian Suatu Pendekatan Praktik. Jakarta: Rineka Cipta

2012.Dasar-Dasar

Evaluasi

Pendidikan. Jakarta: PT Bumi Aksara

Arsyad, A. 2014.Media Pembelajaran. Jakarta: Rajawali Pers.

Aunurrahman. 2009. Belajar dan Pembelajaran. Bandung: Alfabeta.

Budiningsih, Asri. 2002. Belajar dan Pembelajaran. Yogyakarta: FIP UNY.

Cahyo, Agus N. 2013. "Panduan Aplikasi Teori-Teori Belajar Mengajar Teraktual Dan Terpopuler." DIVA Pers: Yogyakarta.

Shoimin, Aris. 68AD. "Model Pembelajaran Inovatif Dalam Kurikulum 2013."

Daryanto. 2010. Media Pembelajaran. Yogyakarta: Gava Media.

Depdiknas. 2003. Undang-Undang RI Nomor 20 Tahun 2003. Tentang Sistem Pendidikan Nasional.

Djamarah, Syaiful Bahri. 2011. Psikologi Belajar. Jakarta: Rineka Jaya.

Hamalik, Oemar. 2007. Psikologi Pendidikan. Bandung: Sinar Baru Algensido.

Kemendikbud.Peraturan Menteri Pendidikan dan Kebudayaan Nomor 59 Tahun 2013. Tentang Kurikulum 2013

Mulyasa. 2013. Pengembangan dan Implementasi Kurikulum 2013. Bandung: PT Remaja Rosdakarya

Purwanto. 2014. Hasil Evaluasi Belajar. Yogyakarta: Pustaka Belajar.

Putrayasa, Made, Dkk. 2014.Pengaruh Model Pembelajaran Discovery Learning dan Minat Belajar Terhadap Hasil Belajar IPA Siswa. Jurnal Mimbar PGSD Universitas Ganesha PGSD. Vol. 2 No.1.

Rusman. 2015. Pembelajaran Tematik Terpadu. Jakarta: Raja Grafindo Persada. 
Shanaky, Hujair. 2013. Media Pembelajaran InteraktifInovatif. Yogyakarta: Kaukaba.

Slameto. 2010. Belajar dan Faktpr-Faktor Yang Mempengaruhinya. Jakaeta: Rineka Cipta.

Sudjana, Nana dan Ahmad Rivai. 2005.Metode Statistika. Bandung: Remaja Rosdakarya.

Sugiyono. 2013. Metode Penelitian Pendidikan. Bandung: Alfabeta.

Suprijono, Agus. 2009. Cooperative Learning Teori dan Aplikasi PAIKEM. Yogyakarta: Pustaka Belajar.

Susanto, A. 2016.Teori Belajar dan Pembelajaran di SD. Jakarta: Prenadamedia Grup

Thobroni. 2017. Belajar dan Pembelajaran. Yogyakarta: Ar-Ruzz Media.

Trianto. 2007. Model-Model Pembelajaran Inovatif Beroirientasi Konstruktivistik. Jakarta: Prestasi Pustaka. 